STUDIA PRAWNO-EKONOMICZNE, T. CVI, 2018

PL ISSN 0081-6841; $\quad$ e-ISSN 2450-8179 $\quad$ s. 197-219

https://doi.org/10.26485/SPE/2018/106/12

Janusz BRZESZCZYŃSK|*

Jerzy GAJDKA ${ }^{* *}$

Ali M. KUTAN***

\title{
FOREIGN EXCHANGE MARKET RESPONSES TO INTEREST RATE ANNOUNCEMENTS EVOLVE OVER TIME? EVIDENCE FROM POLAND
}

\begin{abstract}
(Summary)
Evidence from the international markets shows that the responsiveness of financial instruments' prices to monetary policy announcements tends to weaken in a low level interest rate environment. The objective of our study is to verify if a similar effect existed in Poland when interest rate decreased from high to low levels over time. The focus of our paper is the currency market. We use GARCH class models with dummy variables as our main methodological tool. In the case of interest rate announcements, we distinguish between the nominal changes in interest rate and surprise changes. The surprise component is extracted by comparing the actual NBP announcements regarding the change of the interest rate with market expectations captured by the consensus forecasts from Reuters surveys of financial market participants in Poland. The results from our study demonstrate that in a lower interest rate environment, the foreign exchange market in Poland has become less responsive to interest rate decisions. We also find evidence that the reactions of foreign exchange rate returns tend to be stronger in case of interest rate changing upwards rather than downwards. Our results about the evolv-
\end{abstract}

* Professor, Department of Accounting and Financial Management, Newcastle Business School, Northumbria University, Newcastle-upon-Tyne, United Kingdom; e-mail: janusz. brzeszczynski@northumbria.ac.uk and Department of Capital Market and Investments, Faculty of Economics and Sociology, University of Łódź, Łódź, Poland.

** Professor, Department of Capital Market and Investments, Faculty of Economics and Sociology, University of Łódź, Łódź, Poland; e-mail: jgajdka@uni.lodz.pl

${ }^{* * *}$ Professor, Department of Economics and Finance, School of Business, Southern Illinois University Edwardsville, Edwardsville, IL, USA; e-mail: akutan@siue.edu 
ing nature of reactions of the foreign exchange market in Poland in both high and low interest rate environments may provide helpful information for policymakers about the impact of their policy decisions.

Keywords: Macroeconomic Announcements, Interest Rate, National Bank of Poland (NBP), Foreign Exchange Rates, Foreign Exchange Market Reactions

JEL classification: E5, F3, G1, O2, P3

\section{Introduction}

Existing empirical evidence based on international data indicates that the responsiveness of financial markets to monetary policy announcements changes (usually weakens) in a low level interest rate environment.

For example, $\mathrm{Wu}(2016)^{1}$ analyzed the effectiveness of Federal Reserve Board (FRB) interest rate announcements in the period of changing levels of interest rate in the USA and found that money market and bond market instruments' reactions depended on their term (e.g. short-term treasury bonds sensitivity was reduced in the low level interest rate period). In the US stock market, the responses also varied but with respect to time: the stock prices' reactions weakened in the sub-period of years 2008-2010 and then strengthened afterwards.

The objective of our study is to verify if similar effects existed in Poland when interest rate decreased to lower levels over time. Due to space considerations, in this paper we focus only on the currency market.

We investigate the reaction of the foreign exchange rate returns in Poland to the National Bank of Poland (NBP) announcements of interest rate changes. Our data sample covers 15 years, which includes the periods of both high and low levels of interest rate, and it spans from August 2000, when the NBP started to make on regular basis its announcements regarding the new monetary policy data, up until July 2015.

The reactions of the foreign exchange market in Poland are measured relative to the changes in interest rate and to the surprise changes. The surprise component is extracted by comparing the actual NBP announcements regarding the change of the interest rate with market expectations. We capture market

\footnotetext{
W. Wu, Are Financial Markets Less Responsive to Monetary Policy Shocks at the Zero Lower Bound?, Economics Letters 2016/145, pp. 258-261.
} 
expectations through the consensus forecasts from Reuters surveys of financial market participants in Poland.

The purpose of this paper is to answer the question whether foreign exchange market responses to interest rate changes in Poland evolve over time depending on the level of interest rate (in particular in a low level interest rate environment). We focus on Poland due to the fact that it is the largest financial market in Central and Eastern Europe (CEE) and it was also one of the first countries in the entire CEE region which implemented transparent communication policies with financial markets.

Our research is related to the following other earlier papers using the data from international markets: Bernanke, Kuttner (2005)², Gómez, Melvin, Nardari $(2007)^{3}$, Hanousek, Kočenda, Kutan (2009) ${ }^{4}$, Melvin, Saborowski, Sager, Taylor $(2010)^{5}$, Conrad, Lamla (2010) ${ }^{6}$, Hausman, Wongswan (2011) ${ }^{7}$, Hayo, Neuenkirch (2012) ${ }^{8}$, Wright (2012) ${ }^{9}$, Kiley $(2014)^{10}$, Swanson, Williams (2014) ${ }^{11}$,

2 B.S. Bernanke, K.N. Kuttner, What Explains the Stock Market's Reaction to Federal Reserve Policy?, Journal of Finance 2005/60, pp. 1221-1257.

3 M. Gómez, M. Melvin, F. Nardari, Explaining the Early Years of the Euro Exchange Rate: An Episode of Learning about a New Central Bank, European Economic Review 2007/51, pp. 505-520.

4 J. Hanousek, E. Kočenda, A.M. Kutan, The Reaction of Asset Prices to Macroeconomic Announcements in New EU Markets: Evidence from Intraday Data, Journal of Financial Stability 2009/5, pp. 199-219.

5 M. Melvin, C. Saborowski, M. Sager, M.P. Taylor, Bank of England Interest Rate Announcements and the Foreign Exchange Market, International Journal of Central Banking 2010/6, pp. 211-247.

6 C. Conrad, M.J. Lamla, The High-Frequency Response of the EUR-USD Exchange Rate to ECB Communication, Journal of Money, Credit and Banking 2010/42, pp. 1391-1417.

7 J. Hausman, J. Wongswan, Global Asset Prices and FOMC Announcements, Journal of International Money and Finance 2011/30, pp. 547-571.

8 B. Hayo, M. Neuenkirch, Domestic or U.S. News: What Drives Canadian Financial Markets?, Economic Inquiry 2012/50, pp. 690-706.

9 J.H. Wright, What Does Monetary Policy Do to Long-Term Interest Rates at the Zero Lower Bound?, Economic Journal 2012/122, pp. F447-F466.

10 M.T. Kiley, The Response of Equity Prices to Movements in Long-Term Interest Rates Associated with Monetary Policy Statements: Before and After the Zero Lower Bound, Journal of Money, Credit and Banking 2014/46, pp. 1057-1071.

11 E.T. Swanson, J.C. Williams, Measuring the Effect of the Zero Lower Bound on Mediumand Longer-Term Interest Rates, American Economic Review 2014/104, pp. 3154-3185. 
Gilchrist, López-Salido, Zakrajšek (2015) ${ }^{12}$, von Borstel, Eickmeier, Krippner $(2016)^{13}$, and $\mathrm{Wu}(2016)^{14}$.

Other related papers, which used Polish market data, include: Ziarko-Siwek $(2004)^{15}$, Serwa $(2006)^{16}$, Rozkrut, Rybiński, Sztaba, Szwaja (2007) ${ }^{17}$, Włodarczyk $(2008)^{18}$, Demchuk, Łyziak, Przystupa, Sznajderska, Wróbel (2012) ${ }^{19}$, Janecki (2012) ${ }^{20}$, Ziarko-Siwek (2013) ${ }^{21}$, Kubacki (2014) ${ }^{22}$, Kapuściński, Łyziak, Przystupa, Stanisławska, Sznajderska, Wróbel (2014) ${ }^{23}$, Brzeszczyński, Kutan $(2015)^{24}$, and Baranowski, Gajewski (2016) ${ }^{25}$, among others.

12 S. Gilchrist, D. López-Salido, E. Zakrajšek, Monetary Policy and Real Borrowing Costs at the Zero Lower Bound, American Economic Journal: Macroeconomics 2015/7, pp. 77-109.

13 J. von Borstel, S. Eickmeier, L. Krippner, The Interest Rate Pass-Through in the Euro Area During the Sovereign Debt Crisis, Journal of International Money and Finance 2016/68, pp. 386-402.

14 W. Wu, op. cit.

15 U. Ziarko-Siwek, Ocena Efektywności Informacyjnej Wybranych Segmentów Rynku Finansowego w Polsce, Materiały i Studia NBP 2004/178, Narodowy Bank Polski, Warszawa.

16 D. Serwa, Do Emerging Financial Markets React to Monetary Policy Announcements? Evidence from Poland, Applied Financial Economics 2006/16, pp. 513-523.

17 M. Rozkrut, K. Rybiński, L. Sztaba, R. Szwaja, Quest for Central Bank Communication: Does it Pay to Be 'Talkative'?, European Journal of Political Economy 2007/23, pp. 176-206.

18 T. Włodarczyk, Wpływ wypowiedzi i komentarzy członków Rady Polityki Pieniężnej na krzywa dochodowości. Badanie pótsilnej efektywności informacyjnej rynku kontraktów FRA i swapów procentowych, Bank i Kredyt 2008/2, pp. 43-59.

19 O. Demchuk, T. Lyziak, J. Przystupa, A. Sznajderska, E. Wróbel, Mechanizm transmisji polityki pieniężnej w Polsce. Co wiemy w 2011 roku?, Materiały i Studia NBP 2012/270, Narodowy Bank Polski, Warszawa.

20 J. Janecki, Reakcja rynkowych stóp procentowych na zmiany stopy procentowej banku centralnego w Polsce $w$ latach 2001-2011, Materiały i Studia NBP 2012/272, Narodowy Bank Polski, Warszawa.

${ }^{21}$ U. Ziarko-Siwek, Efekt ogłoszeń jako wyraz przejrzystości polityki pieniężnej, Ekonomista 2013/1/2003, pp. 71-98.

22 D. Kubacki, Comparison of the Information Efficiency of the Financial Markets in Selected European Union Countries on the Event "Central Bank Information About Changing or Not Changing the Level of the Reference Rate", Journal of Management and Financial Sciences 2014/7, pp. 75-92.

23 M. Kapuściński, T. Lyziak, J. Przystupa, E. Stanisławska, A. Sznajderska, E. Wróbel, Mechanizm transmisji polityki pieniężnej w Polsce. Co wiemy w 2013 roku?, Materiały i Studia NBP 2014/306, Narodowy Bank Polski, Warszawa.

${ }^{24}$ J. Brzeszczyński, A.M. Kutan, Public Information Arrival and Investor Reaction During a Period of Institutional Change: An Episode of Early Years of a Newly Independent Central Bank, Journal of Comparative Economics 2015/43, pp. 727-753.

25 P. Baranowski, P. Gajewski, Credible Enough? Forward Guidance and Perceived National Bank of Poland's Policy Rule, Applied Economics Letters 2016/23, pp. 89-92. 
Our study also addresses some of the gaps, which were identified in the literature on emerging markets, and that were discussed in the review paper by Brzeszczyński, Gajdka and Kutan $(2015)^{26}$.

\section{Data}

The database includes daily frequency data from the foreign exchange market in Poland. Our sample covers the period from 1 August 2000 to 31 July 2015. August 2000 was chosen as the beginning of the sample because it was the first month which marked the start of regular announcements of key monetary policy data made by the Polish central bank NBP. The total number of observations in the selected sample is 3,914 .

We construct models for daily returns of foreign exchange rates for $P L N$ exchange rates against the major international currencies: PLN/EUR, PLN/USD, $P L N / G B P, P L N / C H F$ and $P L N / J P Y$. This choice of currency pairs was determined by their size and market share.

Sources of data in our database include: National Bank of Poland (the data for announcements dates and interest rate data), ThomsonReuters (expectations from Reuters surveys) as well as Datastream and Bloomberg (foreign exchange market data).

\section{Methodology}

We model reactions of the foreign exchange market and we use dummy variables to capture the effects of the NBP announcements. Because strong ARCH effects were detected in all models, we utilize GARCH methodology as our approach. GARCH models are a natural and very convenient methodological framework to investigate the effects of announcements in both the mean equation and the conditional variance equation. However, due to space constraints, in this paper we focus only on the effects in the mean equation.

The impact of the NBP communication with financial markets is captured by constructing dummy variables for interest rate change announcements for the announcement date (i.e. day $t$ ). We investigate models with the dummy

26 J. Brzeszczyński, J. Gajdka, A.M. Kutan, Investor Response to Public News, Sentiment and Institutional Trading in Emerging Markets: A Review, International Review of Economics and Finance 2015/40, pp. 338-352. 
variables for the announcement days when: (i) interest rate went up or down and (ii) announcements of interest rate changes were the same or different from market expectations.

As mentioned earlier, for the construction of surprise interest rate changes dummies we used the consensus forecasts from Reuters surveys of financial market participants in Poland. Additionally, we compared and confirmed this survey data with consensus views found in historical articles and newswires from news agencies, which were published before the announcements of the Monetary Policy Council decisions.

The data frequency in all the models constructed and analysed in this study is daily ${ }^{27}$.

We start with the estimation of the following $\operatorname{GARCH}(1,1)$ models of PLN/EUR, PLN/USD, PLN/GBP, PLN/CHF and PLN/JPY foreign exchange rate returns with the NBP interest rate announcement dummies introduced in the mean equation:

$$
\begin{gathered}
r_{t}^{i}=\alpha_{0}+\alpha_{1} \cdot D U M_{t}+\xi_{t} \\
\xi_{t}=\vartheta_{t} \sqrt{h_{t}} \\
h_{t}^{i}=\beta_{0}+\beta_{1} \cdot \xi_{t-1}^{2}+\beta_{2} \cdot \sigma_{t-1}^{2}
\end{gathered}
$$

where:

$r_{t}^{i}$ - is the $r$ daily return of the foreign exchange rate $i$

$i=P L N / E U R, P L N / U S D, P L N / G B P, P L N / C H F$ and $P L N / J P Y$

$D U M_{t}-$ is the dummy variable capturing the relevant interest rate changes and $\vartheta_{t}: \operatorname{IID}(0,1)$ i.e. $\vartheta_{t}$ is identically and independently distributed with a mean of zero and a variance of one, while the error term has the distribution $\xi_{t}: \operatorname{IID}\left(0, \sigma_{\xi}^{2}\right)$.

27 It is worthwhile to mention here that the use of the daily frequency data makes the relationship between foreign exchange rate returns and the interest rate recursive (i.e. the causality runs from the interest rate to the foreign exchange rate), yet in the case of lower frequency data (which is, however, not the subject of investigation in this study) such relationship would most probably be simultaneous. We thank the anonymous Referee for this comment. 
Subsequently, we also extend the above specification by adding the returns of the respective foreign exchange rates against the basket of currencies in order to control for the possible interrelationships among the currencies:

$$
\begin{gathered}
r_{t}^{i}=\alpha_{0}+\alpha_{1} \cdot D U M_{t}+\alpha_{2} \cdot r_{t}^{j / \text { basket }}+\xi_{t} \\
\xi_{t}=\vartheta_{t} \sqrt{h_{t}} \\
h_{t}^{i}=\beta_{0}+\beta_{1} \cdot \xi_{t-1}^{2}+\beta_{2} \cdot \sigma_{t-1}^{2}
\end{gathered}
$$

where for every foreign currency $j$, i.e. for $j=E U R, U S D, G B P, C H F$ and $J P Y$ : $r_{t}^{j / b a s k e t}-$ is the daily return of the respective foreign exchange rate against the basket of currencies (e.g. for the EUR against the basket of currencies, it is: $r_{t}^{\text {EUR/basket }}$ etc.).

The source of the data for the foreign exchange rates against the basket of currencies is Bloomberg ${ }^{28}$.

Each equation is designed to include always only one dummy variable, so the estimates of the dummy parameters are obtained separately for each individual dummy variable.

In all models we tested for autocorrelation and heteroscedasticity. If autocorrelation was detected, we removed it by imposing an appropriate structure of AR and/or MA terms. In cases when heteroscedasticity was persistent, we estimated higher orders of GARCH models and we also checked their other functional forms (such e.g. EGARCH etc.), which was necessary to remove any remaining heteroscedasticity.

28 The data about the international currencies basket from Bloomberg relies on the Bloomberg correlation-weighted currency indices for the major global currencies from the G-10 countries. Hence, the weights in the basket are allocated using the Bloomberg methodology to measure correlation among foreign exchange rates (rather than other traditional trade-weighted benchmarks). Such an approach better reflects the composition of the international currency basket because this new methodology designed by Bloomberg not only captures the common movements between currency pairs in the basket, but also better explains the variation within the basket and it is able to adapt on a daily basis to changing market conditions. 


\section{Empirical Results}

Tables $1 \mathrm{a}-5 \mathrm{a}$ and $1 \mathrm{~b}-5 \mathrm{~b}$ present estimation results for parameters from the models for all five currency pairs: PLN/EUR, PLN/USD, PLN/GBP, $P L N / C H F$ and $P L N / J P Y$ in both variants with and without the returns of the respective international foreign exchange rates against the basket of currencies, respectively.

The dummy variables called "Interest Rate Change Upwards" and "Interest Rate Change Downwards" are constructed for the days on which the NBP interest rate was changed upwards or downwards, respectively. The dummy variable called "Interest Rate Change the Same as Expected" captures the situation when the actual change of the interest rate was exactly the same as expected by the market (according to the Reuters surveys), while the dummy "Interest Rate Change Higher than Expected (i.e. 'Positive Surprise')" indicates that the actual change of the interest rate was higher than expected by the market whereas the dummy "Interest Rate Change Lower than Expected (i.e. 'Negative Surprise')" indicates that the actual change of the interest rate was lower than expected by the market. All these three dummy variables capture only the direction of the deviations from the market expectations (but not the size of the deviation) ${ }^{29}$.

In order to capture the reactions of the foreign exchange market in high level and low level interest rate environments, we divided the entire sample into two equal sub-samples: August 2000 - January 2008 (high interest rate period with the NBP reference rates ${ }^{30}$ ranging from $17.50 \%$ to $5.25 \%$ ) and February 2008 - July 2015 (low interest rate period with the NBP reference rates ranging from $5.25 \%$ to $1.50 \%$ ).

The results in all tables indicate that the best fitting variants of the estimated GARCH class models were GARCH $(1,1)$ and $\operatorname{GARCH}(1,2)$ specifications.

The results in Tables $1 \mathrm{a}-5 \mathrm{a}$ and $1 \mathrm{~b}-5 \mathrm{~b}$ depict the following general patterns.

29 We opted to use only the binary variables as our dummies to indicate the interest rate changes and the direction of the deviations from the market expectations (rather than the size of the changes) because of the relatively small number of interest rate decisions during the entire sample period (splitting the interest rate decisions into more categories with respect to the size of the change would result in a situation where in some sub-samples many of such dummy variables would be taking on only the values equal to 0 , so the estimation results across the sub-samples would not be comparable).

30 The NBP reference rate is the minimum money market intervention rate. 
First, the reactions of the foreign exchange rate returns tend to be stronger in the case of interest rate changing upwards rather than downwards. However, the overall picture is mixed in the case of surprises (i.e. when interest rate was announced at a level different than expected).

This result may be related to the effect of the changing level of interest rate over time (i.e. a surprise change of, for example, 25 bps is interpreted differently by the markets in the period when interest rates are high or low, e.g. when the interest rate is $12 \%$ then a 25 bps change is a much smaller fraction of it than in the case when the interest rate is $4 \%$ ).

Second, the analysis of the differences across the sub-samples of high and low level interest rate reveals that there is a dominance of a larger number of results which are statistically significant (i.e. 7 cases versus 2 cases) in the first sub-period (a higher interest rate environment) than in the second subperiod (a lower interest rate environment). Hence, we can conclude that there exists some evidence that in a lower interest rate environment the foreign exchange market in Poland became less responsive to interest rate decisions. This finding confirms the results from the literature for some other markets (e.g. Wu $(2016))^{31}$.

31 W. Wu, op. cit. 


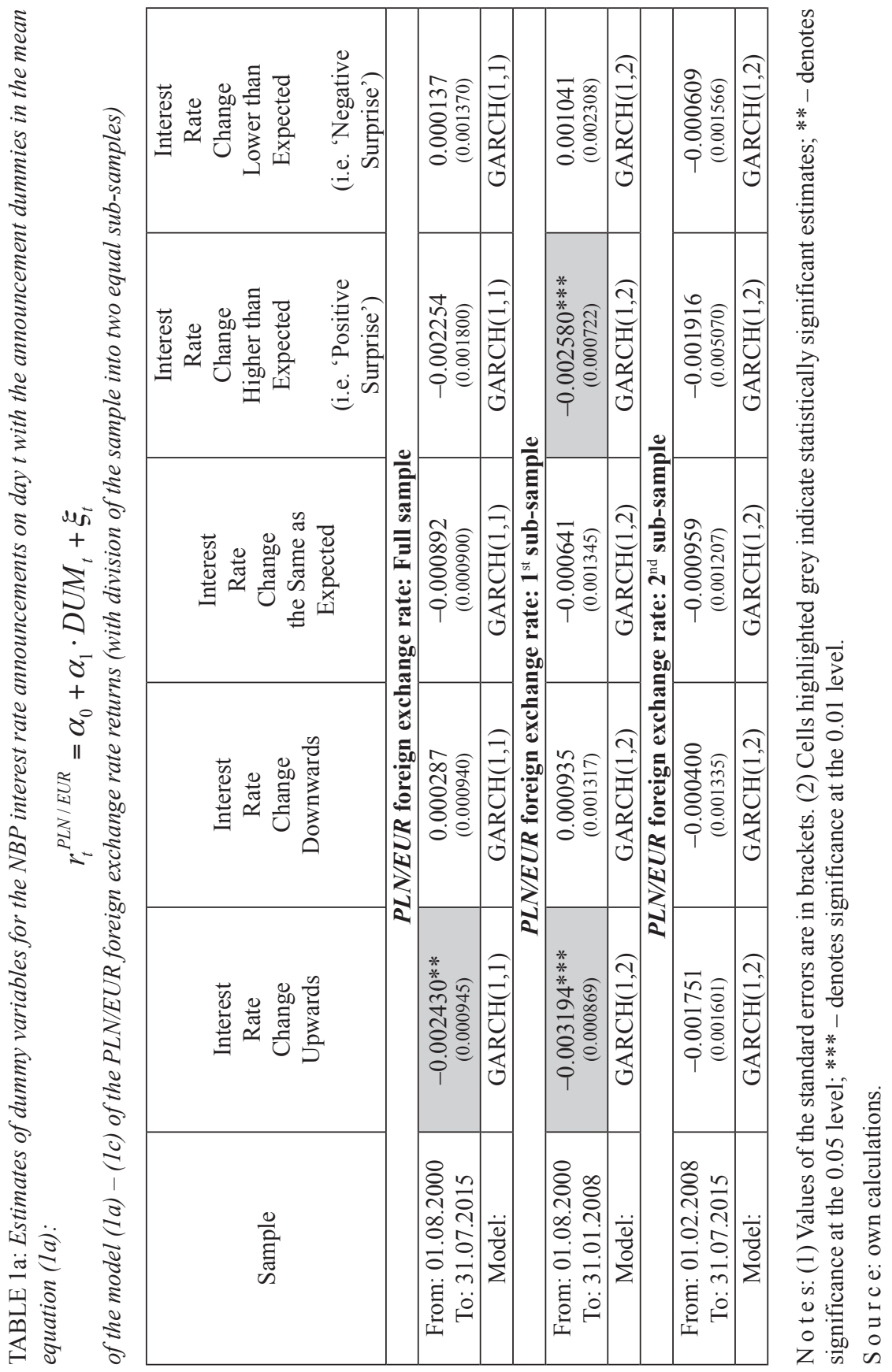




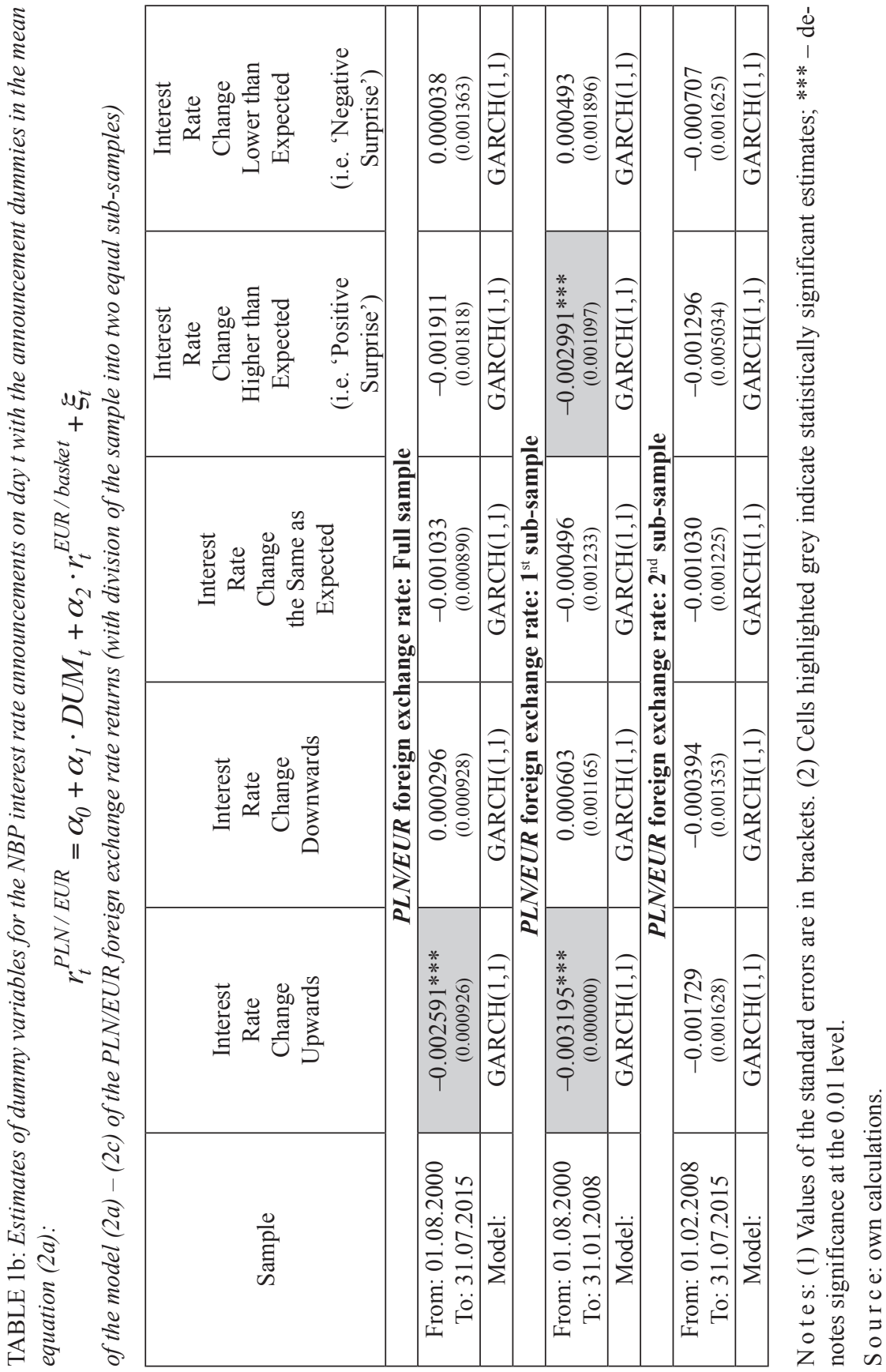




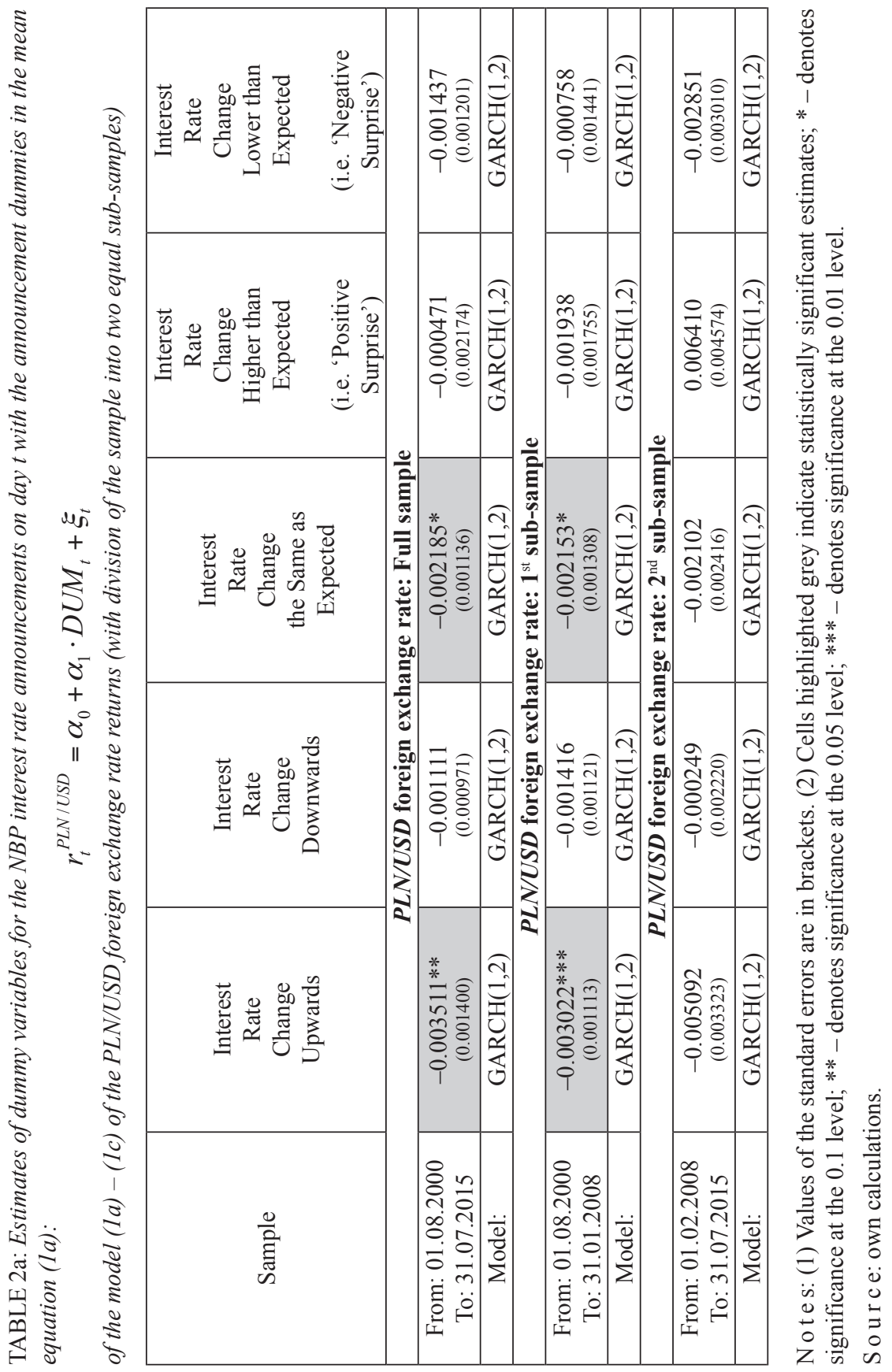




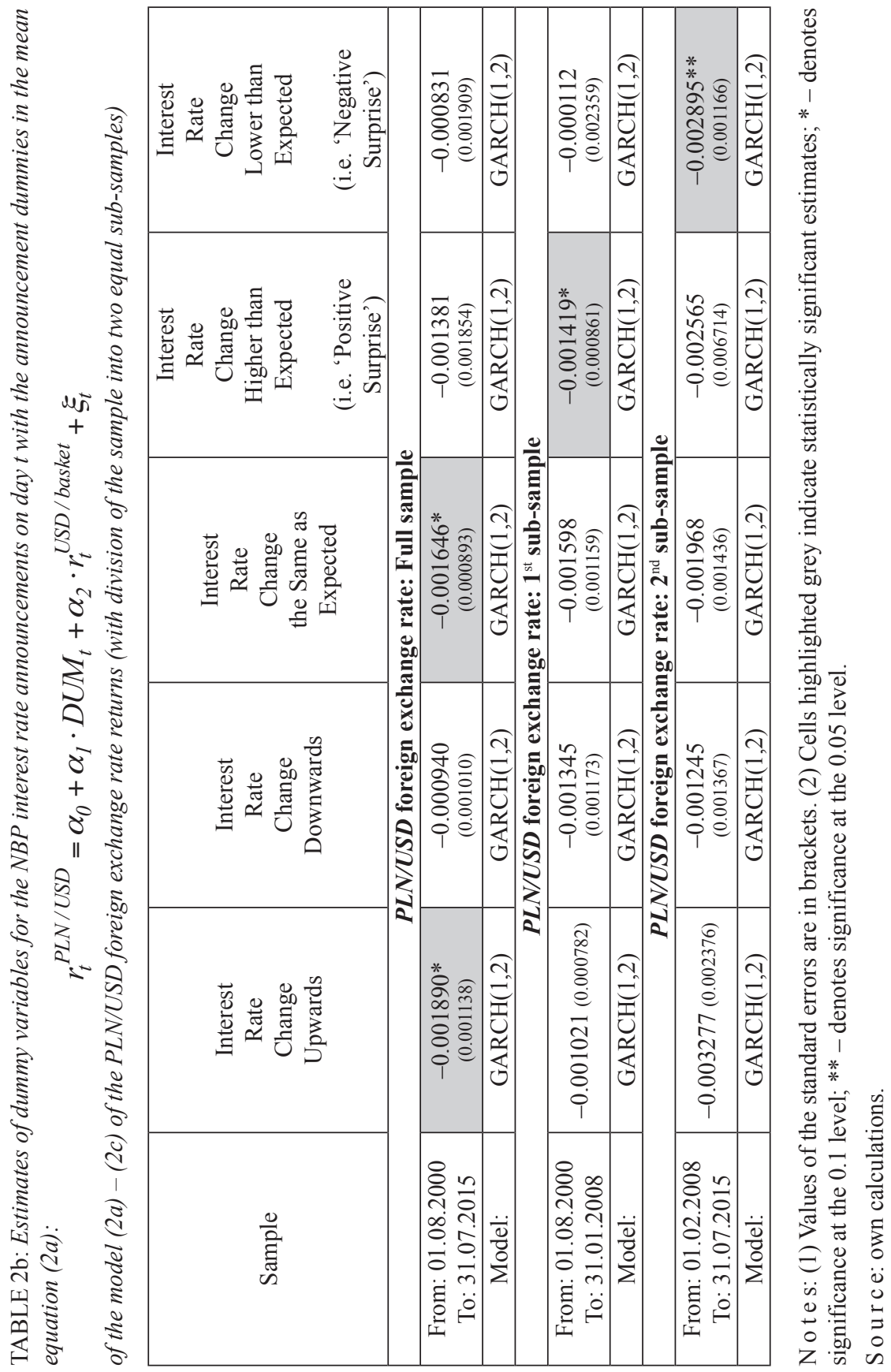




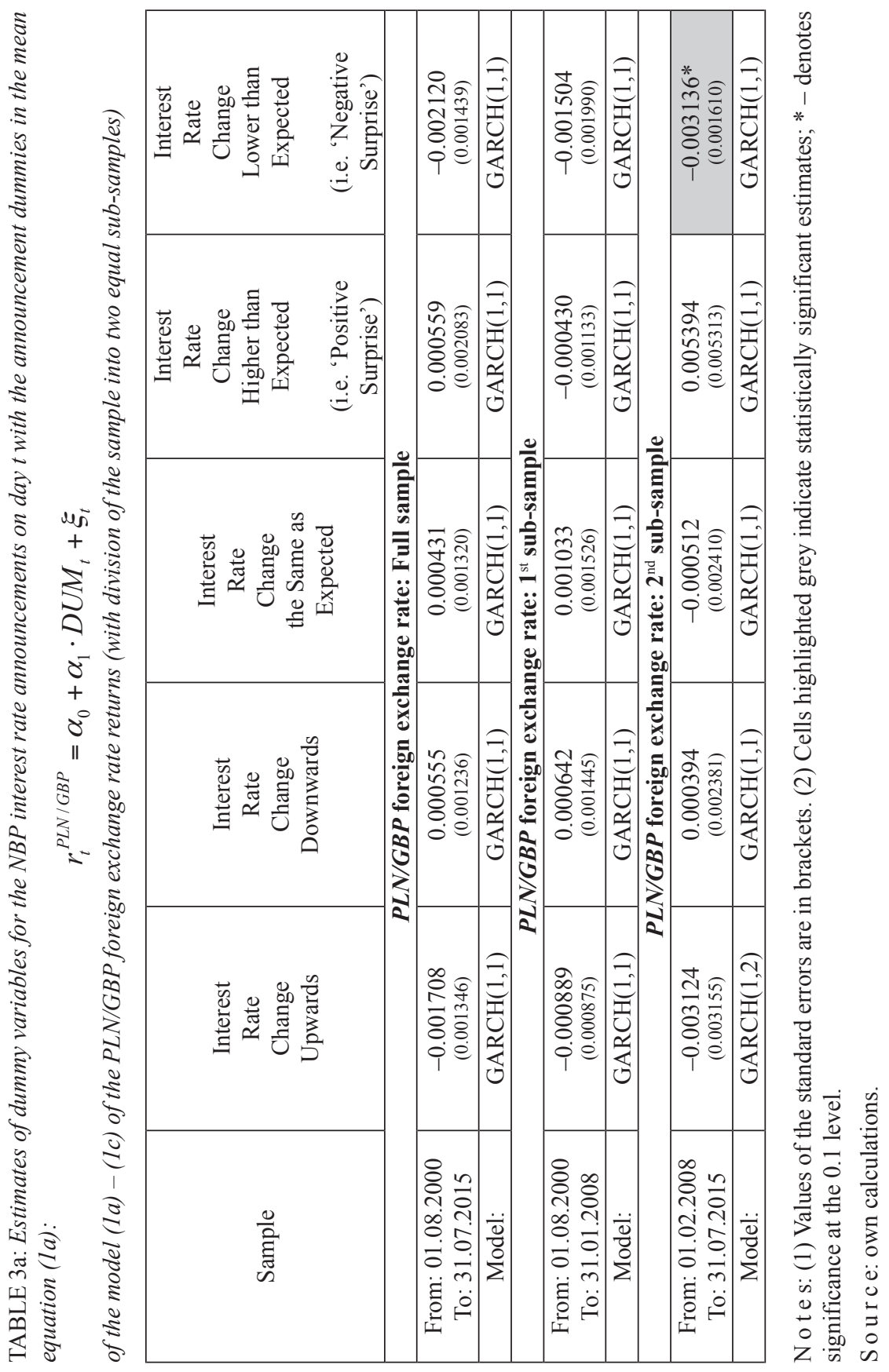




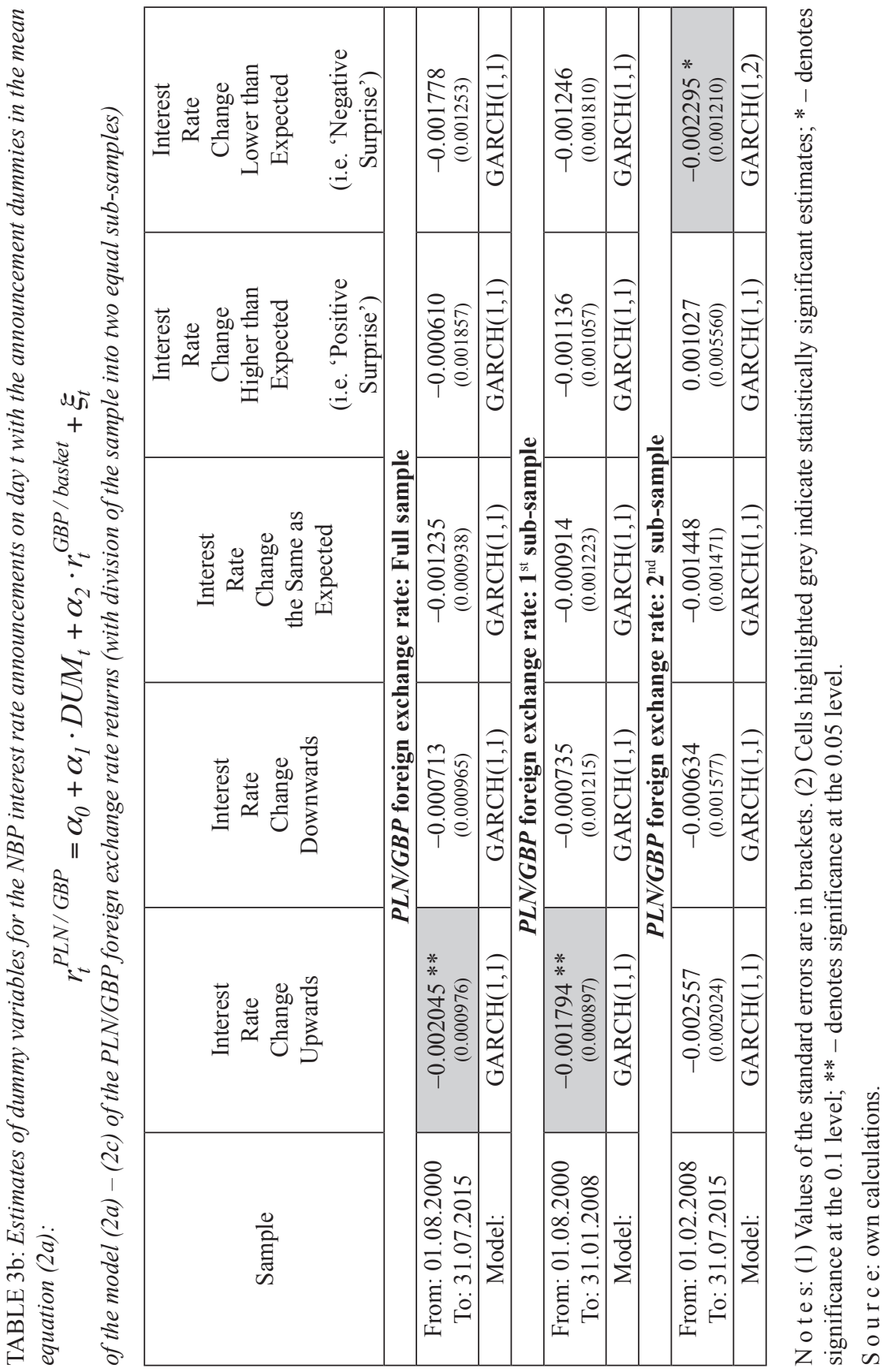




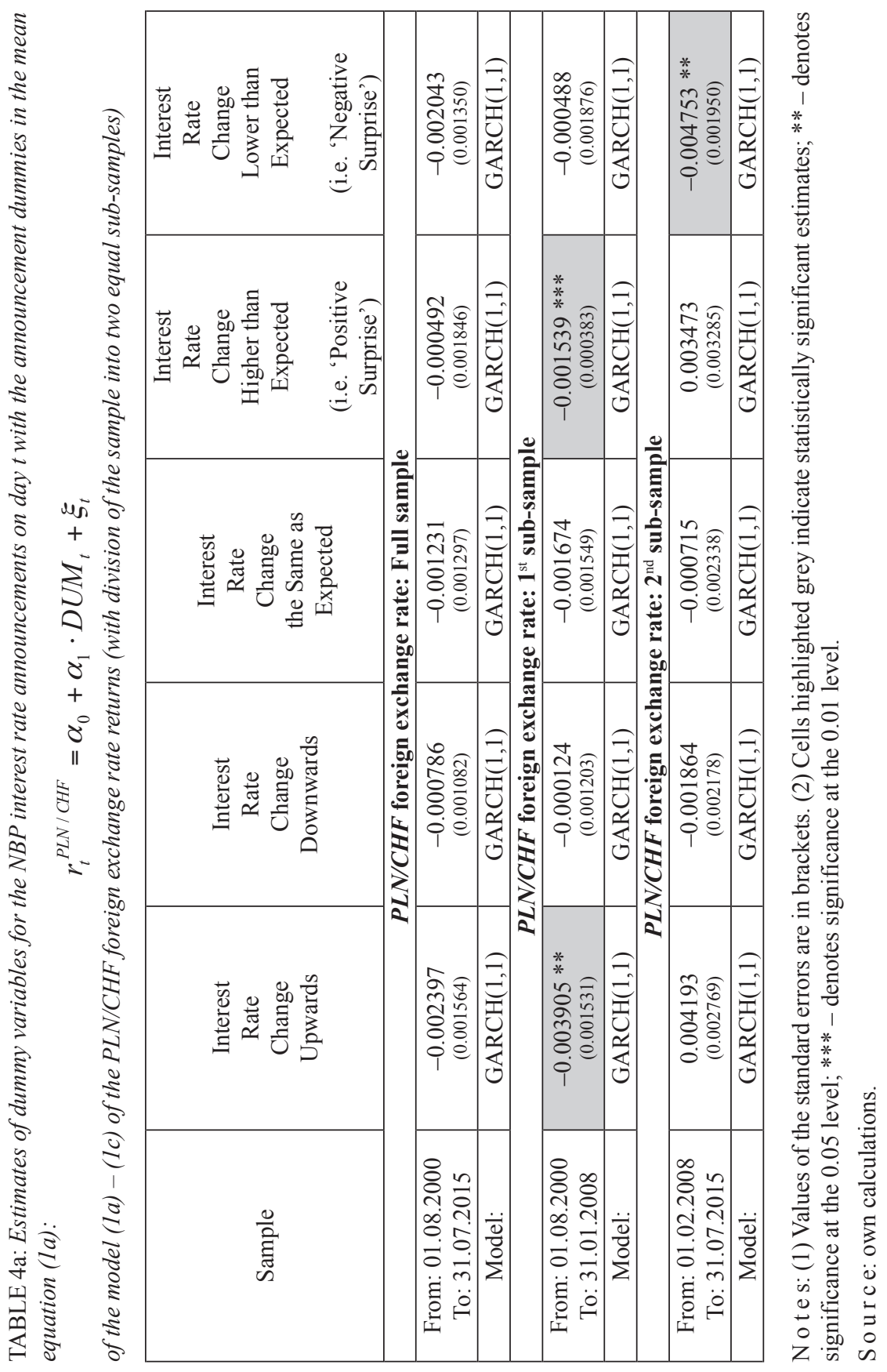




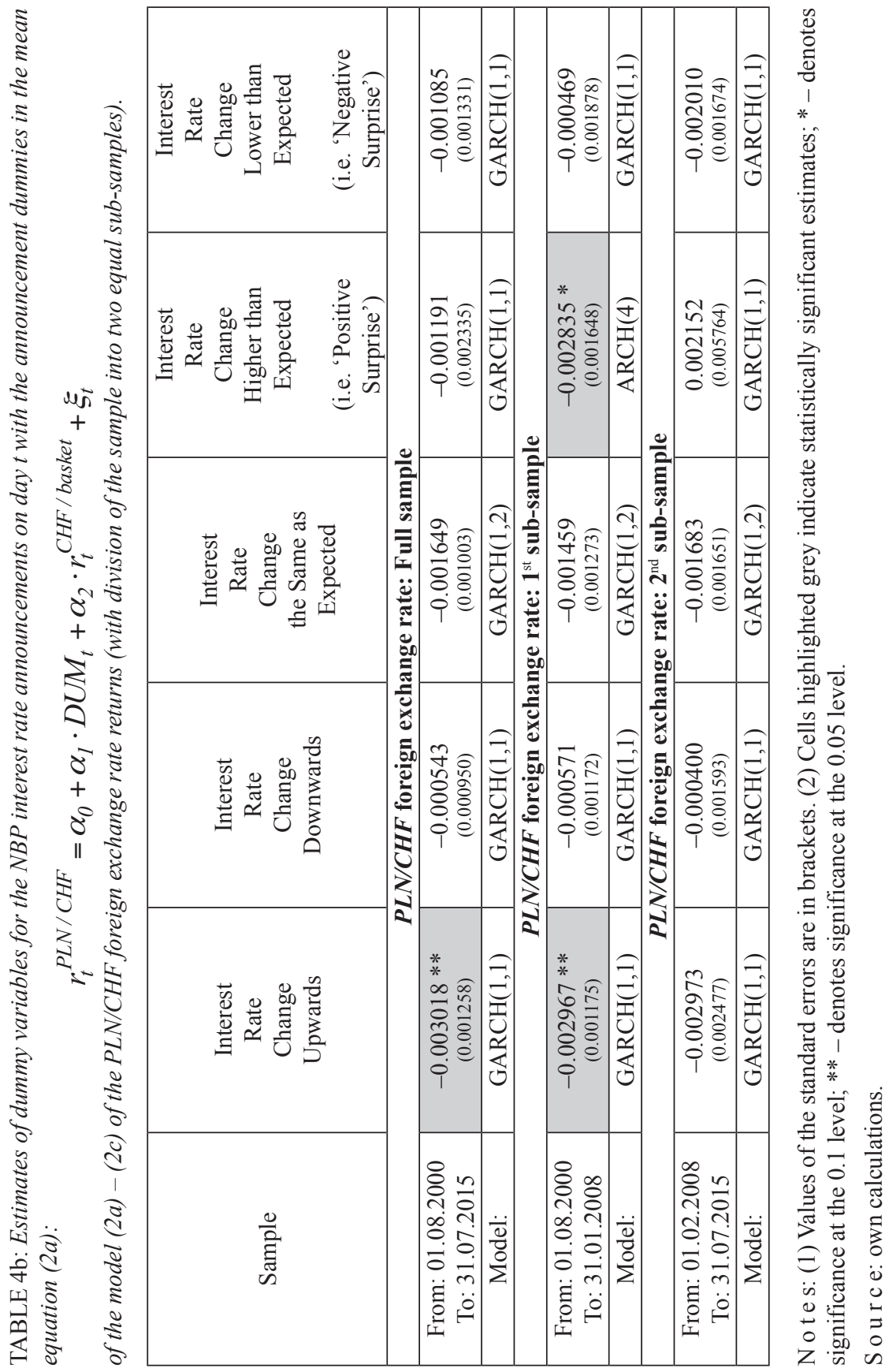




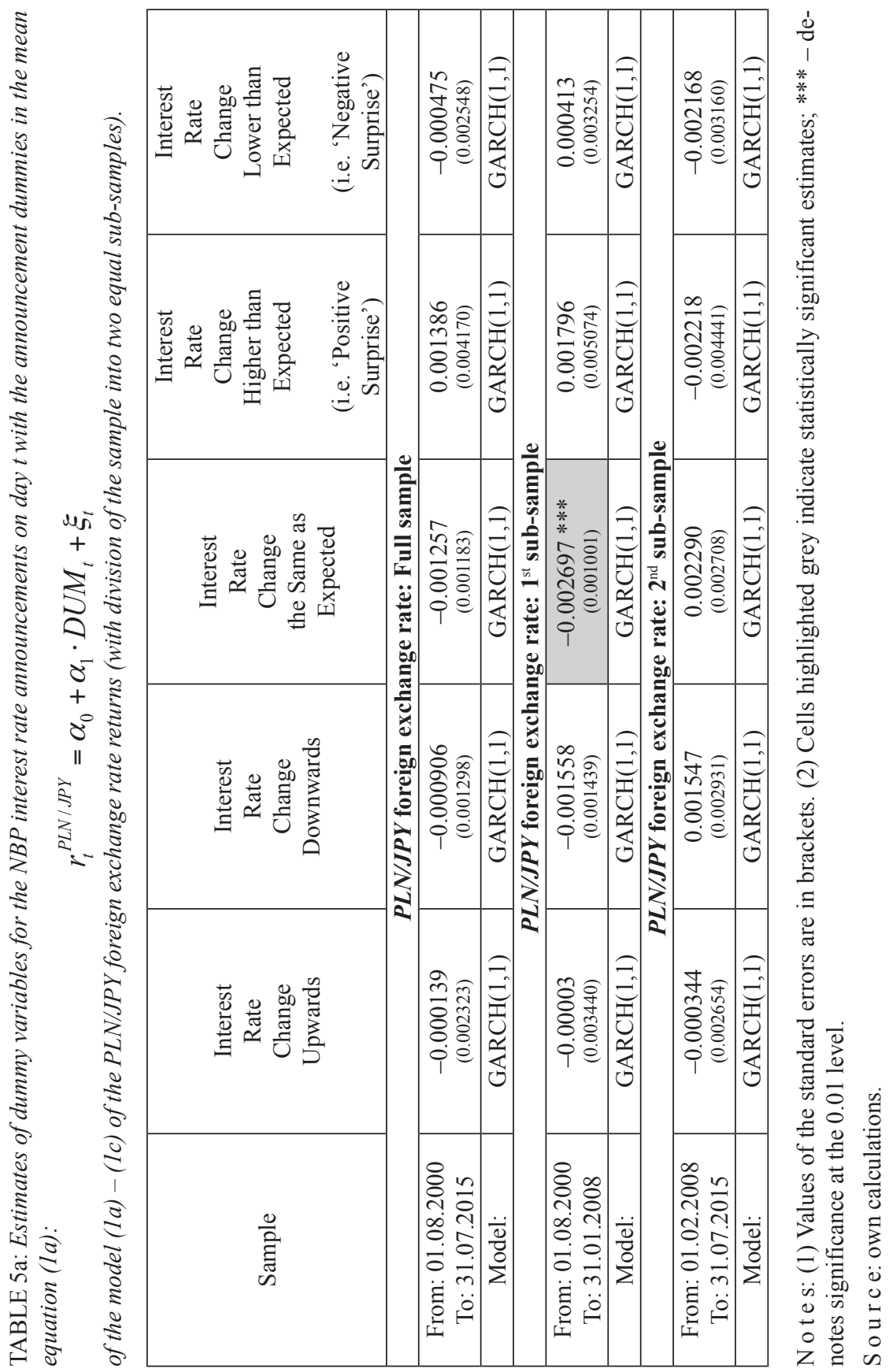




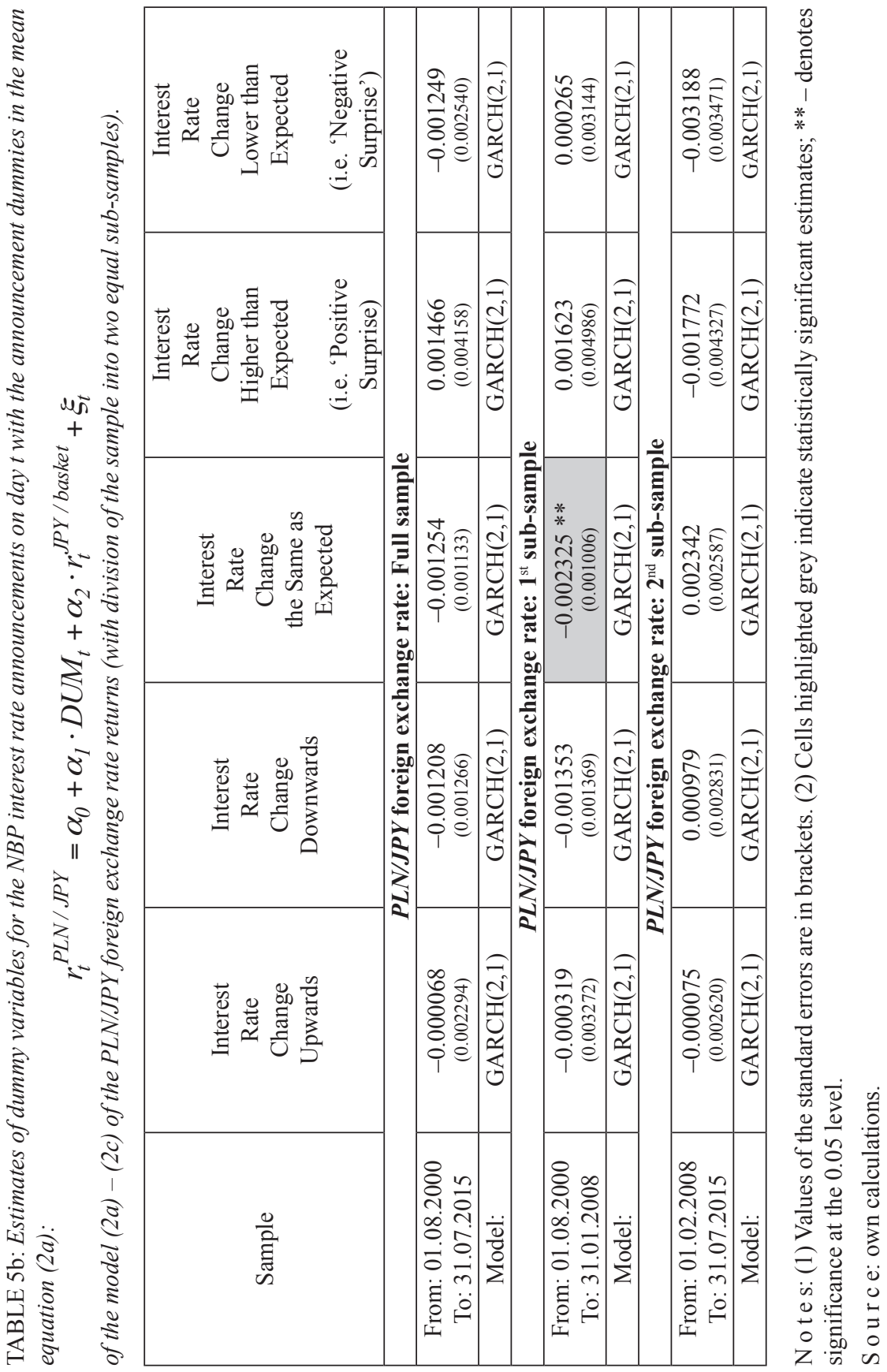


Our results also indicate the possibility of 'wealth effects' that potentially can be exploited by foreign exchange market investors. Hence, from this point of view the findings from this study are consistent with the conclusions from, e.g., the paper by Brzeszczyński \& Kutan (2015) ${ }^{32}$.

\section{Robustness Checks}

As a robustness check, we compared the estimates of all dummy variables from Tables $1 \mathrm{a}-5 \mathrm{a}$ and from Tables $1 \mathrm{~b}-5 \mathrm{~b}$ in order to verify whether the inclusion of the returns of the international foreign exchange rates against the basket of currencies could affect our results. The conclusion is that the overall picture remains the same even after adding this control variable: there is still a strong dominance of statistically significant estimation results (also 7 cases versus 2 cases) in the first sub-period (a higher interest rate environment) than in the second sub-period (a lower interest rate environment).

We also investigated all models in the variants with different divisions of the entire sample period into the sub-samples using other alternative dates around the middle of our sample; however the overall findings remained broadly very similar ${ }^{33}$.

\section{Conclusions}

The results from our study about the evolving nature of reactions of the foreign exchange market in Poland may provide helpful information for policymakers regarding the impact of their policy decisions.

One of the key practical issues related to our research is the question whether the central banks can influence or manipulate currency exchange rates in a low interest rate environment. Because we detected a pattern of weakening reactions to interest rate announcements in the sub-sample with low interest rate, this situation - however - seems unlikely. Therefore, the implication of our results is that any central bank's interest rate policy may not be effective to manipulate trade flows or maintain exchange rates at a desired level in a low interest rate period. This finding, in turn, suggests a larger role for fiscal policy in such environment. Hence, in the case of Poland which has been the subject of analysis

32 J. Brzeszczyński, A.M. Kutan, op. cit.

33 Due to space considerations, we do not present these estimates here, but they are available upon request. 
in this paper, a monetary-fiscal policy coordination seems to be more desired than in the past periods and it should become a more important policy tool now due to the effect of low interest rate.

Our study also indicates some other avenues for future research. The extension of the analysis presented in this paper can include the following other aspects of financial markets' responses to central bank announcements in high and low interest rate environments: investigation of reactions in other market segments (i.e. stock markets and money markets), analysis of effects in the conditional variance of GARCH class models (i.e. the impact on the resolution of uncertainty among investors) and examination of responsiveness of the trading volume as the key measure of market activity.

\section{Acknowledgements}

We would like to thank the participants of the Macromodels '2016 conference in Łódź (held on 14-17 November, 2016) and the $92^{\text {nd }}$ Annual Conference of the Western Economic Association International (WEAI) in San Diego, CA (held on 25-29 June, 2017) for helpful discussions and useful comments on this paper.

\section{References}

Baranowski Pawel, Gajewski Pawel, Credible Enough? Forward Guidance and Perceived National Bank of Poland's Policy Rule, Applied Economics Letters 2016/23, pp. 89-92.

Bernanke Ben S., Kuttner Kenneth N., What Explains the Stock Market's Reaction to Federal Reserve Policy?, Journal of Finance 2005/60, pp. 1221-1257.

Brzeszczyński Janusz, Gajdka Jerzy, Kutan Ali M., Investor Response to Public News, Sentiment and Institutional Trading in Emerging Markets: A Review, International Review of Economics and Finance 2015/40, pp. 338-352.

Brzeszczyński Janusz, Kutan Ali M., Public Information Arrival and Investor Reaction During a Period of Institutional Change: An Episode of Early Years of a Newly Independent Central Bank, Journal of Comparative Economics 2015/43, pp. 727-753.

Conrad Christian, Lamla Michael J., The High-Frequency Response of the EUR-USD Exchange Rate to ECB Communication, Journal of Money, Credit and Banking 2010/42, pp. 1391-1417.

Demchuk Oksana, Lyziak Tomasz, Przystupa Jan, Sznajderska Anna, Wróbel Ewa, Mechanizm transmisji polityki pieniężnej w Polsce. Co wiemy w 2011 roku?, Materiały i Studia NBP 2012/270, Narodowy Bank Polski, Warszawa.

Gilchrist Simon, López-Salido David, Zakrajšek Egon, Monetary Policy and Real Borrowing Costs at the Zero Lower Bound, American Economic Journal: Macroeconomics 2015/7, pp. 77-109. 
Gómez Manuel, Melvin Michael, Nardari Federico, Explaining the Early Years of the Euro Exchange Rate: An Episode of Learning about a New Central Bank, European Economic Review 2007/51, pp. 505-520.

Hanousek Jan, Kočenda Evžen, Kutan Ali M., The Reaction of Asset Prices to Macroeconomic Announcements in New EU Markets: Evidence from Intraday Data, Journal of Financial Stability 2009/5, pp. 199-219.

Hausman Joshua, Wongswan Jon, Global Asset Prices and FOMC Announcements, Journal of International Money and Finance 2011/30, pp. 547-571.

Hayo Bernd, Neuenkirch Matthias, Domestic or U.S. News: What Drives Canadian Financial Markets?, Economic Inquiry 2012/50, pp. 690-706.

Janecki Jarosław, reakcja rynkowych stóp procentowych na zmiany stopy procentowej banku centralnego $w$ Polsce $w$ latach 2001-2011, Materiały i Studia NBP 2012/272, Narodowy Bank Polski, Warszawa.

Kapuściński Mariusz, Lyziak Tomasz, Przystupa Jan, Stanisławska Ewa, Sznajderska Anna, Wróbel Ewa, Mechanizm transmisji polityki pieniężnej w Polsce. Co wiemy w 2013 roku?, Materiały i Studia NBP 2014/306, Narodowy Bank Polski, Warszawa.

Kiley Michael T., The Response of Equity Prices to Movements in Long-Term Interest Rates Associated with Monetary Policy Statements: Before and After the Zero Lower Bound, Journal of Money, Credit and Banking 2014/46, pp. 1057-1071.

Kubacki Dominik, Comparison of the Information Efficiency of the Financial Markets in Selected European Union Countries on the Event "Central Bank Information About Changing or Not Changing the Level of the Reference Rate", Journal of Management and Financial Sciences 2014/7, pp. 75-92.

Melvin Michael, Saborowski Christian, Sager Michael, Taylor Mark P., Bank of England Interest Rate Announcements and the Foreign Exchange Market, International Journal of Central Banking 2010/6, pp. 211-247.

Rozkrut Marek, Rybiński Krzysztof, Sztaba Lucyna, Szwaja Radosław, Quest for Central Bank Communication: Does it Pay to Be 'Talkative'?, European Journal of Political Economy 2007/23, pp. 176-206.

Serwa Dobromil, Do Emerging Financial Markets React to Monetary Policy Announcements? Evidence from Poland, Applied Financial Economics 2006/16, pp. 513-523.

Swanson Eric T., Williams John C., Measuring the Effect of the Zero Lower Bound on Mediumand Longer-Term Interest Rates, American Economic Review 2014/104, pp. 3154-3185.

Włodarczyk Tomasz, Wpływ wypowiedzi i komentarzy członków rady polityki pieniężnej na krzywa dochodowości. badanie pótsilnej efektywności informacyjnej rynku kontraktów FRA i swapów procentowych, Bank i Kredyt 2008/2, pp. 43-59.

Wright Jonathan H., What Does Monetary Policy Do to Long-Term Interest Rates at the Zero Lower Bound?, Economic Journal 2012/122, pp. F447-F466.

Wu Wenbin, Are Financial Markets Less Responsive to Monetary Policy Shocks at the Zero Lower Bound?, Economics Letters 2016/145, pp. 258-261.

von Borstel Julia, Eickmeier Sandra, Krippner Leo, The Interest Rate Pass-Through in the Euro Area During the Sovereign Debt Crisis, Journal of International Money and Finance 2016/68, pp. 386-402.

Ziarko-Siwek Urszula, Ocena Efektywności Informacyjnej Wybranych Segmentów Rynku Finansowego w Polsce, Materiały i Studia NBP 2004/178, Narodowy Bank Polski, Warszawa.

Ziarko-Siwek Urszula, Efekt ogłoszeń jako wyraz przejrzystości polityki pieniężnej, Ekonomista 2013/1/2003, pp. 71-98. 
Janusz BRZESZCZYŃSKI

Jerzy GAJDKA

Ali M. KUTAN

\title{
CZY REAKCJE RYNKU WALUTOWEGO \\ NA DECYZJE O STOPACH PROCENTOWYCH SA ZMIENNE W CZASIE? WYNIKI BADAŃ Z POLSKIEGO RYNKU WALUTOWEGO
}

\author{
(Streszczenie)
}

Rezultaty badań z rynków międzynarodowych wskazują, że reakcje cen instrumentów finansowych w odpowiedzi na decyzje dotyczące polityki pieniężnej są z reguły słabsze w warunkach niskich stóp procentowych. Celem prezentowanej analizy jest weryfikacja, czy podobny efekt występował także w Polsce w czasie, kiedy poziom stóp procentowych zmieniał się z wysokiego do niskiego. Przedmiotem badania w artykule jest rynek walutowy. Głównym narzędziem metodologicznym są modele klasy GARCH ze zmiennymi zero-jedynkowymi. W przypadku decyzji o zmianie stopy procentowej wyróżnione zostały nominalne zmiany stóp oraz ich odchylenia od oczekiwań. Informacja na temat nieoczekiwanej zmiany stóp procentowych uzyskana została poprzez wyznaczenie różnic pomiędzy rzeczywistą zmianą stopy procentowej, ogłoszoną przez Radę Polityki Pieniężnej NBP oraz jej wartością przewidywaną przez rynek w postaci prognoz pochodzących z ankiet agencji Reutera, przeprowadzanych wśród uczestników rynku finansowego w Polsce. Rezultaty zaprezentowanego badania dowodzą, że w warunkach niższych stóp procentowych kursy walutowe w Polsce reagowały słabiej na decyzje dotyczące ich zmian. Ponadto reakcje kursów walut były silniejsze w przypadku wzrostu stóp niż w przypadku ich obniżenia. Wyniki przedstawionych badań na temat ewoluującej w czasie natury reakcji rynku walutowego w Polsce w okresach wysokich oraz niskich stóp procentowych mogą być pomocne w procesach zarządzania polityką pieniężną poprzez lepsze zrozumienie wpływu tego rodzaju decyzji na rynek walutowy.

Słowa kluczowe: publikacja danych makroekonomicznych; stopa procentowa; Narodowy Bank Polski (NBP); kursy walutowe; reakcje rynku walutowego 